\title{
Changes in the preferences for the ecosystem service use and the effects in a city located along a river: a preliminary study based on the example of Torun (Poland) compared to the Isle of Dogs in London
}

\author{
Adam Czarnecki, Anna Lewandowska-Czarnecka, Genowefa Zielińska \\ Nicolaus Copernicus University, Faculty of Biology and Environmental Protection, \\ Chair of Geobotany and Landscape Planning, Lwowska 1, 87-100 Toruń, Poland, \\ e-mail: czarn@umk.pl
}

\begin{abstract}
Ecosystem services originated from various ecological units, local as well as global, hierarchically, they depend on the structure and functions of the ecosystem under study and its human community. They are involved in controlling and maintaining the development of natural resources in the ecosystem, human activities and prosperity through the use of material and non-material benefits. The technology brought in as well as developed by the application of those benefits, enhance the ecological capacity for our human community and in consequences may depend on the decisions brought about by private and public interests. Other forms of ecosystem services also immerge as a direct and indirect product from human pressure on the environment, because the ecosystem exploited by man is most often from a sink of destructive chemical and physical factors, they result in ecosystem services out of an unhealthy environmental state.

This study deals with applicability of the ecosystem service paradigm, and presents the results obtained in Torun, a city developing close to the Vistula River from medieval times. Preference of choice among a wide variety of ecosystem services can be provided in this setting, so it is interesting to compare Torun to other cities where exceptional results are obtained. The reference point in this comparison is a system of similar size but which has developed within a much bigger and stronger urban ecosystem. This is the Isle of Dogs on the Thames River in London.

Our analysis shows that currently, there are strong differences between the two cities in their demand for ecosystem services and their interaction with the public sphere, design and art. On the Isle of Dogs, there is a stronger connection between the ecosystems and the design of space to create an interesting streetscape in comparison to Torun. The connection between the public and private zones to achieve the attractiveness to the city and to combine art and design with environmental solutions has brought about excellent results in London.
\end{abstract}

Keywords: ecosystem services, sustainable cities, development, recreation, urban space.

\section{Introduction}

Making the world's villages, towns and cities environmentally, economically and socially sustainable is the most urgent challenge for mankind in the 21 st century (Kenworthy \& Laube 1996; Mega 2000). Constantly expanding large cities affect the environment and use large amounts of energy. Urban dwellers eat food they do not grow, buy products they do not make, use non-renewable energy, use building materials they do not produce, and so on (Lurton 1998). City expansion and the increased consumption of goods and services, enjoyed with rising standard of living, increase the maintenance costs of the existing system. Thus, by definition and common sense, modern cities cannot be sustainable. Efficiency is one of the key issues closely related to a sustainable city (Jarrar \& Al-Zoabi 2008) as well 
as the impact on land use beyond the city scale (Doughty \& Hammond 2004). Management of complex systems such as cities requires innovative, sophisticated planning tools that can assist in monitoring of current conditions and projection of future developments (Rotmans et al. 2000). Achieving the performance is not an automatic process. Among other considerations, it depends on the city design in relation to the ecosystem and supports and initiatives that produce a balance between public and private goals. The urban space must demonstrate a relationship between ecoservices and the amount of cost savings, and thus the energy cost and consumption and fossil raw materials return. For several reasons this is not an easy task to perform. Namely, an ecosystem provides the whole range of services and products. Most of them may be useless at a given time because a city is supplied with products manufactured in farms and by industry. Also, involvement of the ecosystem services does not guarantee economic success. It may be a component which has a contribution in the success, together with other sources of success (Egger 2006), such as applied in city technology, development of the position in the global system of goods and services exchange etc. Every contemporary city that engages benefits and demonstrates attention to the ecosystem structure however does not obtained a positive impact on the maintaining the system and the attractiveness of living in it. This is because people have different needs and preferences for benefits and they could make a variety of preferential choices. An additional difficulty is that modern cities develop in various directions due to attractiveness of their image and they have different approaches to engagement in ecosystem services. This study deals with the application of the ecosystem service conception in urban areas, and presents the results obtained in Torun a city developed close to the river Vistula from medieval times. Preferences chosen among a wide variety of ecosystem services can be provided in this type of setting, so it is interesting to refer to another city where exceptional results are obtained. The effects of development in places of similar size were compared with a certain part of London, i.e. Isle of Dogs on the river Thames.

\section{Reliance of cities on ecosystems in the past}

Old cities are characterised by various development stages. In the past they were determined mainly by characteristics of a managed ecosystem and coping with challenges of the past. The use of a given ecosystem service depends on engaged supporting activities necessary for all services, including regeneration processes, detoxification, water and air purification (Daily 1997). Demand for ecosystem services is a sum of all ecosystem goods and services currently consumed in a particular area over a given period of time. Early on, a river and a sea enabled the exploration of the natural trophic chain of terrestrial and aquatic ecosystems. In both cases, a river connected with a sea provides life-fulfilling functions and benefits providing as well, a convenient communication route. Alongside, land and marine ecosystems are preserved for options in the future (Millennium Ecosystem Assessment 2005), they may give rise to benefits such as cultural and recreational use, giving an aesthetic sense to a place. Any particular area has a characteristic structure and the capacity (Czarnecki \& Lewandowska-Czarnecka 2012) to provide a specific set of ecosystem goods and services within a given time. The ecosystem services if classified according to their spatial characteristics (Costanza 2008) as global non-proximal, including climate regulation and local proximal, which depends on the proximity of habitats, disturbance regulation and waste assimilation, are important for cities. These detailed provision patterns are part of the ecosystem services, including the part consumed and a surplus used for trade. Different aspects of ecosystem services generation can be considered in the past and at present. In the past natural water reservoirs (oceans, seas, rivers or lakes) were used for exploitation of natural productivity in trophic chains and trade used these natural waterways. In modern times, cultural services as nonmaterial benefits are used for recreation and cultural use (Millennium Ecosystem Assessment 2005). Cities with a long history located on a river went through two major stages in the relationship with an ecosystem resulting (Gómez-Sal et al. 2003) from the potential given by ecosystem and technology and man-operated machines used. Firstly, they used products of the renewable benefits of an ecosystem. Renewable benefits include solar energy, water, or wood, which are never depleted or which can be replaced by a new supply. Inhabitants of towns are directly engaged in exploration of ecosystems. Later, due to demand and technological development they created effective production systems. Valuable goods can replace unlimited resources of fish caught in the open sea; this enabled a very effective trade in the expensive goods of relatively low volumes. With time, rivers were equipped with port facilities and services for shipyard work. The increasing incomes interacted with effective production systems including agriculture, forestry, and construction materials for trade. Nevertheless, resources that are dependent on renewal can sometimes be depleted beyond the point of renewability, as in the case of deforestation of the land. People also used the non-renewable resources to manage ecosystem structures. Humans have also caused changes in the river environment which enabled flood prevention. The industrial activities and consumption produced wastes, which caused pollution of water, air and soil, as well as posing threats to ecosystems. 


\section{Contemporary development of cities}

The development of contemporary cities is influenced by economic, often global systems. The environment has been polluted by the industrial period, and the present generation has to deal with this problem. There are important actions to protect the ecosystem, including protection of the environment and wildlife. A progressive action will require a holistic vision of what is the proper place of nature in the urban environment. Innovative solutions are sought (Strange 1997; Rotmans et al. 2000) for, contrary to solutions representing only the interests of a certain group. Therefore, solutions are sought to address the whole urban ecosystem and an innovative visions for the development. Cities compete with each other by searching for more appealing and miscellaneous forms of attracting tourists and residents, as tourism and travel become an important part of the economy (Ashworth \& Page 2011). Environment protection is part of the development concept, by interacting with characteristics of cities, creating the image depending on the direction of development (Gospodini 2006). This is visible in a polycentric City as well as a compact City which minimizes its ecological impact. In both types, landscape and urban forms are in balance and where buildings and infrastructures are safe and resource efficient. In each analyzed case, different types of benefits from the ecosystem are selected that support the results achieved. It is important to take into account the benefits in terms of efficiency based on the results with use of adequate services (Boyd \& Banzhaf 2007). It depends on stakeholder collaboration that considers biophysical assessment valuation and then opportunities and constraints into strategy and implementation (Cowling et al. 2008; Fisher et al. 2009). The benefits can be achieved through direct promotion or by building the infrastructure that provides greater efficiency and directing it to the important features of the structure and function of the city. Therefore, some projects can be expensive, but it is also possible to involve low-cost benefits. Development of a modern city can depend of the availability of natural resources and sometimes first of all it may depend on other forms of investment (Burkhard et al. 2010). Nevertheless there is a visible effort to create appropriate living conditions (Rogers 1997; OECD 2002), clean environment, attractive buildings, and at the same time to save energy and other resources, such as water. The important role is played by cultural and regulatory ecosystem services which, when properly exposed, enhance the development. Changes in a city reflect a vision of unknown potential in nature and culture, or have a conservative character. Sometimes decisions may have negative consequences for sustainable development of a city. The important measure is a total value of the ecosystem services; this consists of the sum of ecological, socioeconomical and economical benefits, which shows its impact on human well-being (Faber et al. 2002). If its effect is poor it may cause a consequent migration of people to a culturally and recreationally more desirable place. This has the effect of enlarging another city space and exacerbating atmospheric conditions and efficient energy use.

\section{Stable characteristics of Toruń and its development in the past}

The city founded by the Teutonic Knights was located near the Vistula River, $200 \mathrm{~km}$ from the inner sea in a deeply indented river valley bed with several terraces about $40 \mathrm{~m}$ below the moraine (Fig. 1). It was the best possible location for the city as it is close to the river (Fig. 2) and yet above the flooded terrace, which gives the city security and enables it to control the movement of ships along the river. The surrounding land limited the opportunities for development and expansion; the river provided fish and sand resources, and transport possibilities. The terrestrial ecosystem provided wood, floated down the river for commercial purposes. Its amount is limited by time regeneration of trees. Farming was of a rather subsistence form. The technology of transport into the sea (about $200 \mathrm{~km}$ ) using sails, with a wind of unpredictable direction and power, did not provide many possibilities. On the other hand, the depth of the river was sufficient for navigation. On the whole, the benefits of the location were not great enough at that time to build special facilities near the river, which would support service of a larger number of ships or their repair and construction. The port infrastructure was developed in a modest range, and included a winter port with a small workshop for ship repair. During the development of production systems, based on monocultural agriculture

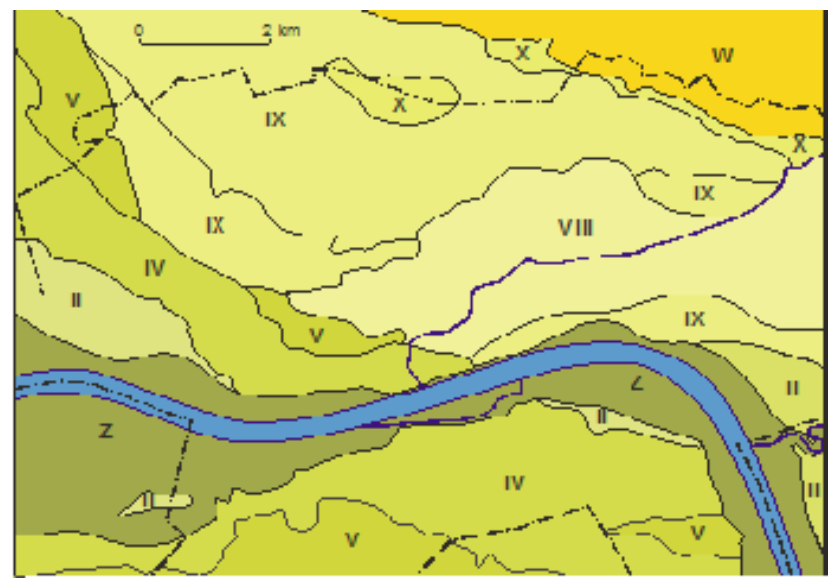

Figure 1. The size and the number of terraces in the Vistula River valley near Toruń (explanations: W-moraine plateau; VIII-X - terrace of Vistula old valleys II-V -Vistula terraces; Z - flood plain of Vistula, border of the city 


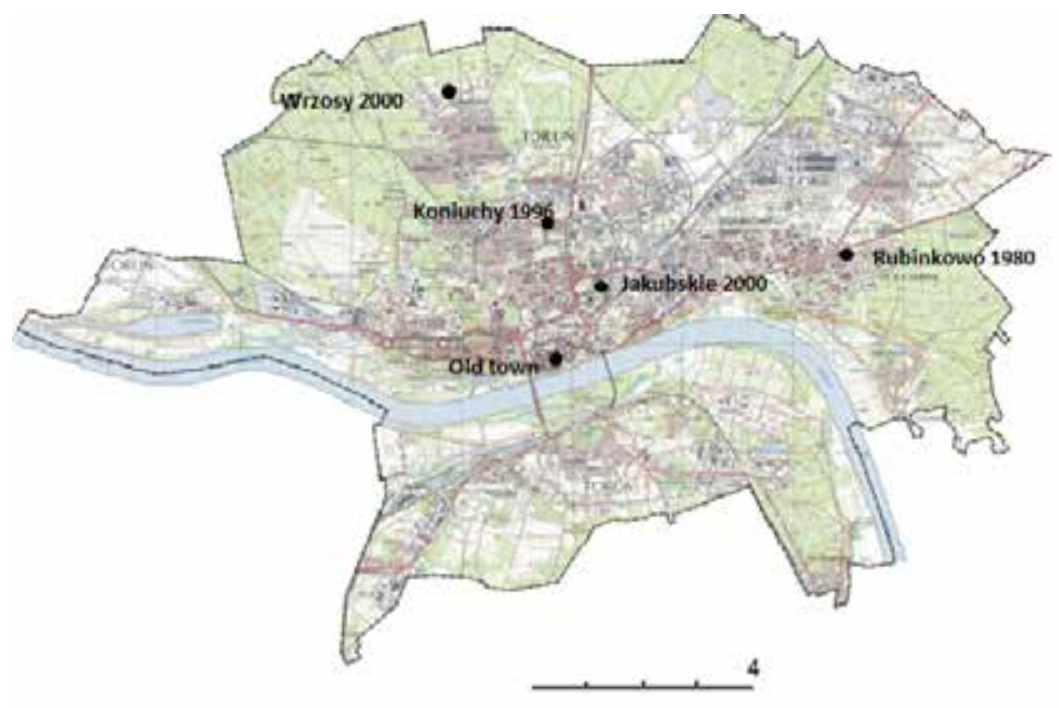

Figure 2. The urban area and new estates in Torun (years of creation are given on the map next to estates' names)

and forestry, the city invested in a wharf and two internal reservoirs for the development of transport services. Small industries were supplied by energy from rivers flowing into the Vistula near Torun. Later with the growing size of ships driven by machine and the increased volume of goods produced; a plan for the river was carried out based on a narrowing of the Vistula river bed so as to create conditions for sailing of barges of 400 tonnes. In the 1970's functions and services of aquatic ecosystems were abandoned. They were replaced by land transport and non-renewable energy was used.

\section{The research objective and methods of analysis}

The objective of this study was to find a city form most close to sustainable state, as well as understanding the value of the citizens' system in relation to the use of ecosystem services and their contribution to other sources of well-being. The cause-effect method is applied to predict consequences. It was investigated with a consideration to observe the relationship between public and private spaces in the city structure (Fig. 3), also how the population interacts, as relevant infrastructures are management and technology is used. Directions of changes were determined, which were then referred to previous stages of development. In this approach rather qualitative indicators were used. Basic services were considered, including provisioning (food, clean water), regulating (climate) and cultural roles by way of spiritual, recreation services. A potential supply of ecosystem services was considered, typical for a place and actual demand for ecosystem services. The effects of balance achieved on the background the economic potential and the use of other sources of well-being in that art, design and value of ecosystems for relaxation was studied. Assessment was made due to the importance and capacity of services and management in cultural and social norms. The paper is based on statistical data and personal observations.

The assessment takes into account changes in technology, innovation and economic conditions for the selected ecosystem services; it also includes the investment and operating costs.

\section{Results}

Nowadays, cities take part in organizing and functioning of the economic system through the most profitable economic activities, based on advanced technologies and global markets. Production systems that remained after the industrial era consist of infrastructure, including artificial water reservoirs and port commodities, manufacturing plants and houses, which often lost its useful function. This is accompanied by polluted soil and water, presenting a potential threat to the ecosystem. There is necessity for intensifying the efforts to protect the ecosystem structures. In many cities, the economic activity that dominates consists of financial support for production, trade and other development. Currently, residential housing and infrastructure developed in cities, is used for communication and transportation of its population, and recreation areas express the quality of life as well as developing tourism. Torun had lesser deve- 


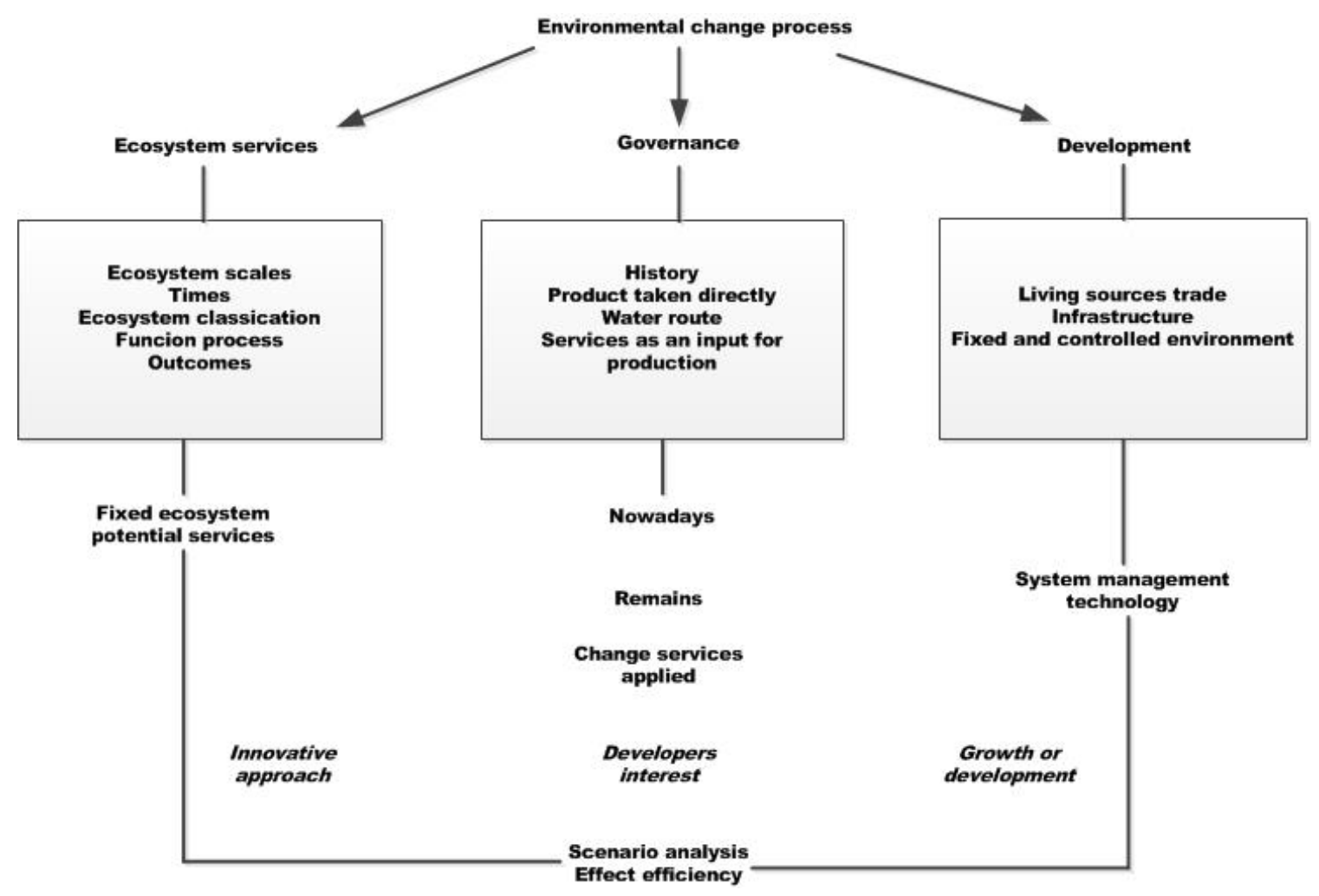

Figure 3. Scheme presented the concept of analysis

lopment opportunities based on the ecosystem; moreover it was limited to a local and regional level. At present, both cities actively develop their economic systems and have an overall concern for environmental status, this has a positive impact on the maintenance of ecosystem functions. Both cities changed their approach to the ecosystem services used for creating a structure and functioning of the city, and an immaterial local function becomes a very important feature for the quality of life including recreation in the city. Due to competition and needs of its inhabitants, cities react differently to the ecosystem exploited in order to achieve defined benefits, the effects are different in terms of sustainability. At present, Torun moves away (Table 1, Photos 1-6) from the river after losing its former harbour in the river embankments and transport functions. The remaining infrastructure is limited to two reservoirs, which are not completely used. Also, activities with the gravel extraction have ceased, and recreation and water sports are very limited. Housing development has significantly increased in recent years. These settlements are built mostly on the upper terraces of the Vistula river valley in an eastern-west direction, reaching the moraine plateau. Private space around buildings, multi-family and single-family houses in suburban residential areas are large and green. Such a number of estates substantially fill the space. Design of houses is not considered particularly outstanding, apart from the multifunctional old city; the public space includes the multicenter with shops and service centres. Torun has become a vast city with a low density of 1,520 inhabitants per $\mathrm{km}^{2}$. Land use planning is focused on the dynamically developing infrastructure, including the road system. There is a rather efficient flow within the urban system, the green area is appreciated as it improves the microclimate and becomes a certain barrier against the noise and dispersion of pollutants. Forests located close to urban areas and old parks play the same role. The adjacent woodland is also treated as an unstructured yet an organized recreation area. Other immaterial benefits from the ample landscape management as part of the public streetscape are not considered. The old city has also lost the connection with the river. The city as a whole is car dependent, cars produce pollution and traffic is time consuming and costly for city boundaries and its citizens. 


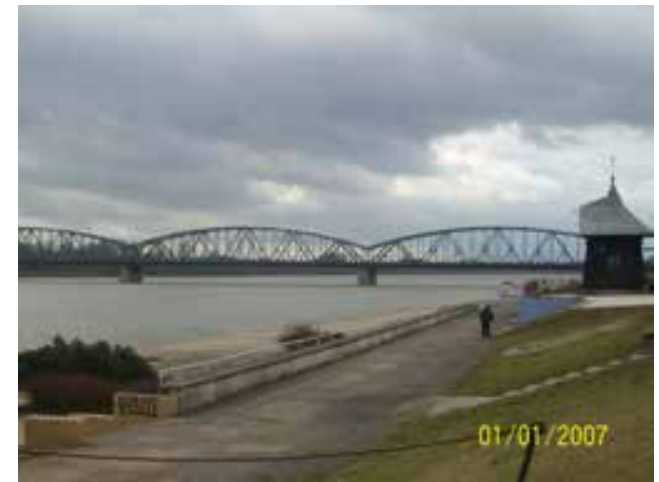

Photo 1. Empty embankments without a port functions in Torun during winter

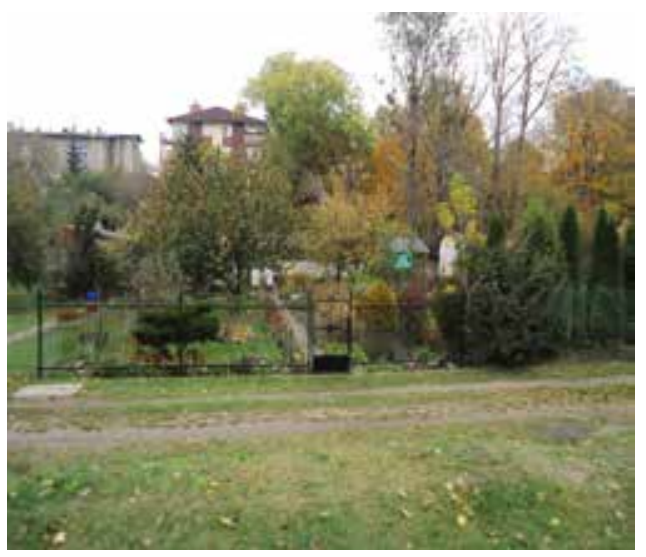

Photo 3. Lower terraces of Vistula river not exposed in city

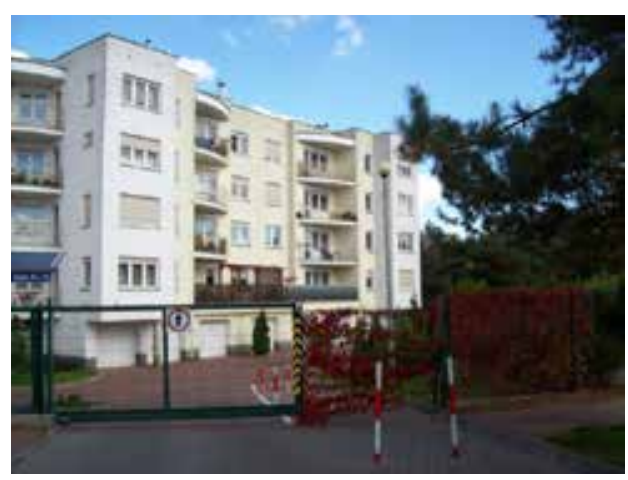

Photo 5. Housing estate situated on the verge of higher terrace

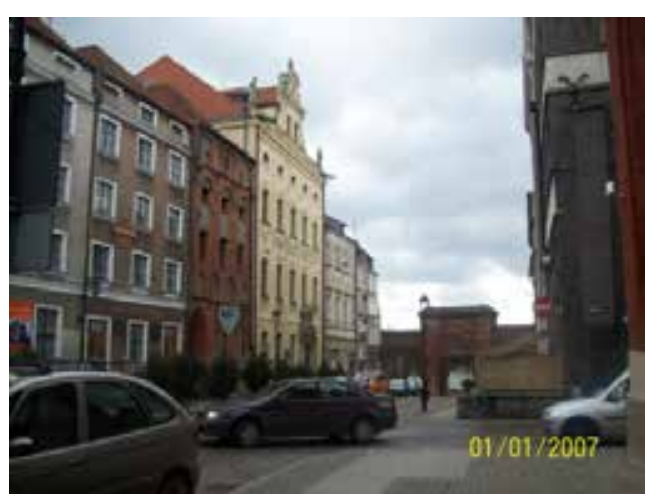

Photo 2. Street on old city going to river

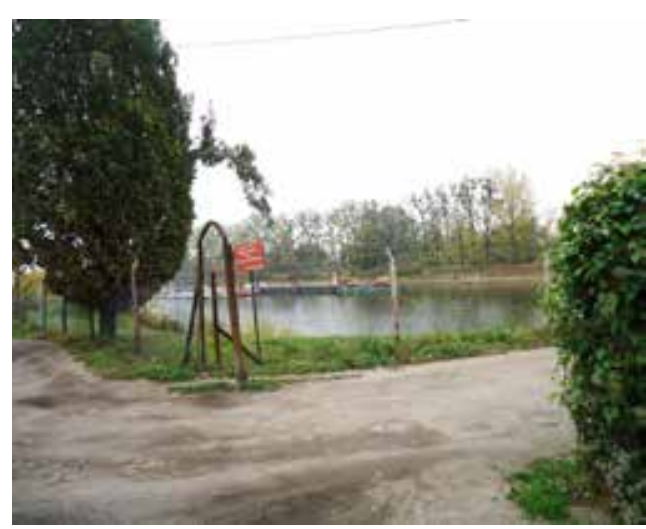

Photo 4. Abandoned not revitalized port

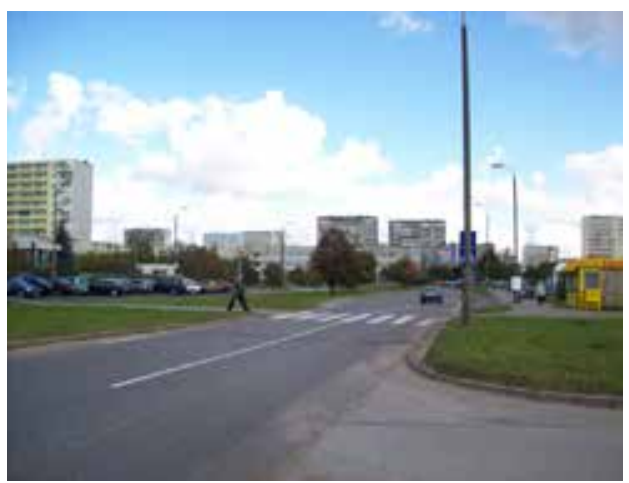

Photo 6. Numerous multifamily houses on flat and vast terrace 
Table 1. Torun - ecosystem services applied in the growth and development

\begin{tabular}{|c|c|c|c|c|c|c|c|}
\hline $\begin{array}{l}\text { Stage } \\
\text { development }\end{array}$ & $\begin{array}{l}\text { Ecosystem } \\
\text { services }\end{array}$ & $\begin{array}{l}\text { Intermediate } \\
\text { services }\end{array}$ & $\begin{array}{l}\text { Potential } \\
\text { by spatial } \\
\text { characteristics }\end{array}$ & $\begin{array}{l}\text { Ultimate } \\
\text { services }\end{array}$ & $\begin{array}{l}\text { Human input } \\
\text { to ecosystem } \\
\text { services }\end{array}$ & $\begin{array}{l}\text { Present } \\
\text { contribution to } \\
\text { development }\end{array}$ & $\begin{array}{l}\text { Effects - } \\
\text { character of city }\end{array}$ \\
\hline $\begin{array}{l}\text { Nowadays } \\
\text { Economi }\end{array}$ & $\begin{array}{l}\text { Regulating } \\
\text { Cultural }\end{array}$ & $\begin{array}{l}\text { Flooding; } \\
\text { Diversified } \\
\text { sites, } \\
\text { terraces, } \\
\text { marshes. }\end{array}$ & $\begin{array}{l}\text { Local effect of } \\
\text { regional and } \\
\text { local processes; } \\
\text { Elements of } \\
\text { local structures } \\
\text { diversified local } \\
\text { landscape. }\end{array}$ & $\begin{array}{l}\text { Places for } \\
\text { recreation } \\
\text { mainly } \\
\text { forest area } \\
\text { diversified } \\
\text { view on } \\
\text { landscape. }\end{array}$ & $\begin{array}{l}\text { Choosing } \\
\text { higher terraces } \\
\text { embankments in } \\
\text { the city; } \\
\text { On flooding } \\
\text { terraces remains } \\
\text { from past - ponds } \\
\text { and small rivers. }\end{array}$ & \multirow{3}{*}{$\begin{array}{l}\text { Safe location } \\
\text { embankments } \\
\text { buildings on } \\
\text { higher, vast and } \\
\text { flat terraces; } \\
\text { Stable water } \\
\text { conditions water } \\
\text { basin landscape } \\
\text { on higher } \\
\text { terraces not } \\
\text { engaged; } \\
\text { In the public } \\
\text { space } \\
\text { plants around } \\
\text { private estates. }\end{array}$} & \multirow{3}{*}{$\begin{array}{l}\text { Car dependence } \\
\text { Allocation of } \\
\text { area convenient } \\
\text { for housing; } \\
\text { Investment } \\
\text { in effective } \\
\text { transport; } \\
\text { Air protected by } \\
\text { plants in private } \\
\text { spaces; } \\
\text { Streetscape } \\
\text { limited to old } \\
\text { city; } \\
\text { Air polluted by } \\
\text { car } \\
\text { area for } \\
\text { recreation } \\
\text { in urban forest } \\
\text { multicentre city. }\end{array}$} \\
\hline $\begin{array}{l}\text { Past } \\
\text { Productive }\end{array}$ & $\begin{array}{l}\text { Provisioning } \\
\text { Regulating }\end{array}$ & $\begin{array}{l}\text { Fish } \\
\text { population } \\
\text { permanent } \\
\text { current } \\
\text { in one } \\
\text { direction; } \\
\text { Clean water. }\end{array}$ & $\begin{array}{l}\text { Local to } \\
\text { regional Trade. }\end{array}$ & $\begin{array}{l}\text { Water } \\
\text { collection; } \\
\text { Sea } \\
\text { transport; } \\
\text { Trade. }\end{array}$ & $\begin{array}{l}\text { Two water } \\
\text { reservoirs as port } \\
\text { and shipyards } \\
\text { facilities inside } \\
\text { the city. }\end{array}$ & & \\
\hline Ecological & $\begin{array}{l}\text { Provisioning } \\
\text { Fishing }\end{array}$ & & $\begin{array}{l}\text { Diverse and } \\
\text { medium yields } \\
\text { of fish. }\end{array}$ & Logs food. & & & \\
\hline
\end{tabular}

\section{The Isle of Dogs in London as a referred city}

London is situated on the Thames River, a navigable river that crosses the city from the south-west to the east, and is a gate to the open sea. London, being located in the Thames Valley, which is a floodplain surrounded by gently rolling hills. The Thames was once a much broader, shallower river with extensive marshlands; at high tide, its shores reached five times their present width. The Thames is a tidal river, and London is vulnerable to flooding. The Thames has been, however, extensively embanked. Having enough money, the environment and space were created for living in the area, making it slowly independent from the sea and river impact. The famous British expansion used access to the ocean and safe harbour conditions for its prominence. The river provided access to abundant fish resources and provided an opportunity to trade with the world by exchanging the fish for noble metals and spices - goods of rather small size, although very expensive. Over time, there were large coal-powered ships or oil machines with larger capacity for trade. The Isle of Dogs is a former island in the East End of London that is bounded on three sides by one of the largest meanders in the River Thames. There shipyards were developed in that West India Docks, which together strongly contributed to London's prosperity. The past has left a powerful city of great global impact with developed port facilities and numerous industrial buildings, some are now empty. Nowadays, the
Isle of Dogs is subjected to revitalization, the city (Table 2, Photos 7-12) maintains a dense structure and assigns multiple functions over a small area. The city is situated in the area with a stable environment, which in the past was systematically and randomly flooded. The infrastructure used in the past include isolated from the river channels and basins of the port and shipyards. At present, remains of that infrastructure located inside the city are designed as townscapes with a range of zones where water, buildings, interacted with technical devices as locks. The water ecosystem adds a unique charm to skyscrapers in the Canary Wharf, homes and lofts with boat moorings, walking areas, a recreational boating people, commercial and residential population coexist. The two analysed cities studied are part of a global metropolis - the Isle of Dogs as a port of London and Torun as a part of the regional metropolis. Similar ecosystem services are used in both cities, but have different potentials. Hence London's achievements are far greater than those of Torun, because the former effectively used its position in relation to functions and structures of the local ecosystem of the River Thames and the Atlantic Ocean from the regional to the global. With higher productivity from the river and sea fishing, the surplus of which could be traded with many countries all over the world. In the first phase, those services have been turned into the benefits with a small involvement of technology. 
Table 2. The Isle of Dogs - ecosystem services applied in the innovative redevelopment

\begin{tabular}{|c|c|c|c|c|c|c|c|}
\hline $\begin{array}{l}\text { Stage in } \\
\text { development }\end{array}$ & $\begin{array}{l}\text { Ecosystem } \\
\text { services }\end{array}$ & $\begin{array}{l}\text { Intermediate } \\
\text { services }\end{array}$ & $\begin{array}{l}\text { Potential } \\
\text { by spatial } \\
\text { characteristics }\end{array}$ & $\begin{array}{l}\text { Ultimate } \\
\text { services }\end{array}$ & Human input & $\begin{array}{l}\text { Contribution to } \\
\text { development }\end{array}$ & $\begin{array}{l}\text { Present } \\
\text { effects and } \\
\text { character } \\
\text { effectiveness }\end{array}$ \\
\hline $\begin{array}{l}\text { Nowadays } \\
\text { economic }\end{array}$ & $\begin{array}{l}\text { Regulatory } \\
\text { Cultural }\end{array}$ & $\begin{array}{l}\text { Tides } \\
\text { diversified } \\
\text { sites; } \\
\text { Undulating } \\
\text { area marshes. }\end{array}$ & $\begin{array}{l}\text { Local effect } \\
\text { of global } \\
\text { processes } \\
\text { global to local; } \\
\text { Element of } \\
\text { local structures } \\
\text { diversified } \\
\text { local landscape. }\end{array}$ & $\begin{array}{l}\text { Places for } \\
\text { recreation } \\
\text { diversified view } \\
\text { on landscape. }\end{array}$ & $\begin{array}{l}\text { Weirs } \\
\text { embankments } \\
\text { facilities } \\
\text { remains } \\
\text { from the past } \\
\text { Reservoirs } \\
\text { Inside weirs }\end{array}$ & \multirow{3}{*}{$\begin{array}{l}\text { Protection } \\
\text { against } \\
\text { flooding; } \\
\text { Embankments } \\
\text { buildings close } \\
\text { to a river; } \\
\text { Urban } \\
\text { ventilation } \\
\text { corridor; } \\
\text { Public transport } \\
\text { along the river; } \\
\text { Stable water } \\
\text { conditions } \\
\text { inside city; } \\
\text { Nature and } \\
\text { landscape. }\end{array}$} & \multirow{3}{*}{$\begin{array}{l}\text { Innovative } \\
\text { effective } \\
\text { transport; } \\
\text { Optimally } \\
\text { engaged } \\
\text { corridor fresh } \\
\text { air; } \\
\text { Interesting } \\
\text { and } \\
\text { diversified } \\
\text { streetscape; } \\
\text { Microclimate; } \\
\text { Limited car } \\
\text { movement; } \\
\text { Attractive } \\
\text { area for } \\
\text { recreation; } \\
\text { Buildings } \\
\text { close to many } \\
\text { reservoirs } \\
\text { inside city. }\end{array}$} \\
\hline $\begin{array}{l}\text { Past } \\
\text { productive }\end{array}$ & $\begin{array}{l}\text { Provisioning } \\
\text { Regulating }\end{array}$ & $\begin{array}{l}\text { Fish population } \\
\text { changing } \\
\text { currents in } \\
\text { opposite } \\
\text { direction } \\
\text { during day. }\end{array}$ & $\begin{array}{l}\text { Local to global } \\
\text { trade; } \\
\text { Diversity. }\end{array}$ & $\begin{array}{l}\text { Water collection; } \\
\text { Sea transport; } \\
\text { Fish trade } \\
\text { network; } \\
\text { Precious metals } \\
\text { spices. }\end{array}$ & $\begin{array}{l}\text { River } \\
\text { narrowing; } \\
\text { Port and } \\
\text { shipyards } \\
\text { facilities. }\end{array}$ & & \\
\hline $\begin{array}{l}\text { Beginning } \\
\text { from } \\
\text { ecological }\end{array}$ & & Clean water. & $\begin{array}{l}\text { Large yields of } \\
\text { fish. }\end{array}$ & & & & \\
\hline
\end{tabular}

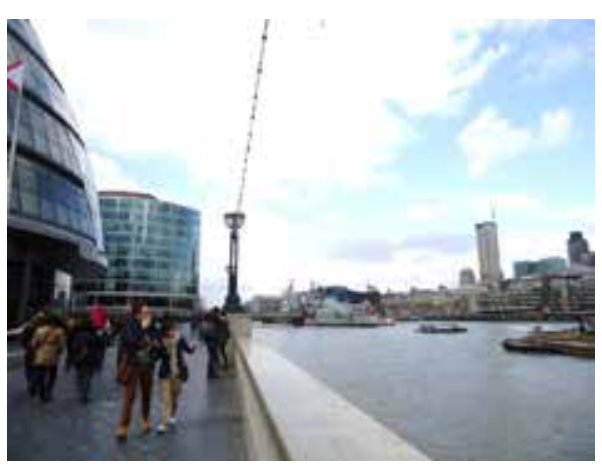

Photo 7. Canary Wharf new buildings

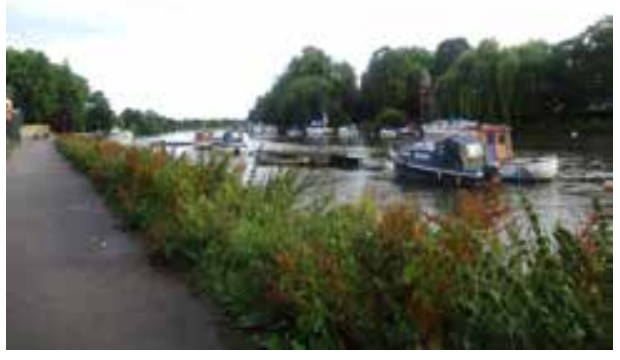

Photo 8. Estates close to water basins with piers around the water basins

\section{Differences between cities according to potential that ecosystem services can provide to its population}

In view of spatial characteristics of the structure of ecosystems, including the specific location and functions, London and Torun differ from one another. These differences are perceived by its resident's as benefits and some as disservices. The size of potential benefits and costs of removing some obstacles in the environment affect the development and expected outcome, as the most favourable benefits require human intervention and effort. Buildings are situated close to the Thames embankments; and there is a lot of very modern architecture. There are recreation places on the bend of the river and walking routes with landscape views. It makes for pleasant living here nevertheless considering the density of 4520 inhabitants per $\mathrm{km}^{2}$. It has become an important part of London which attracts 27 million overnight-stay visitors every year, making it the most visited city in Europe. In addition to traditional functions, 


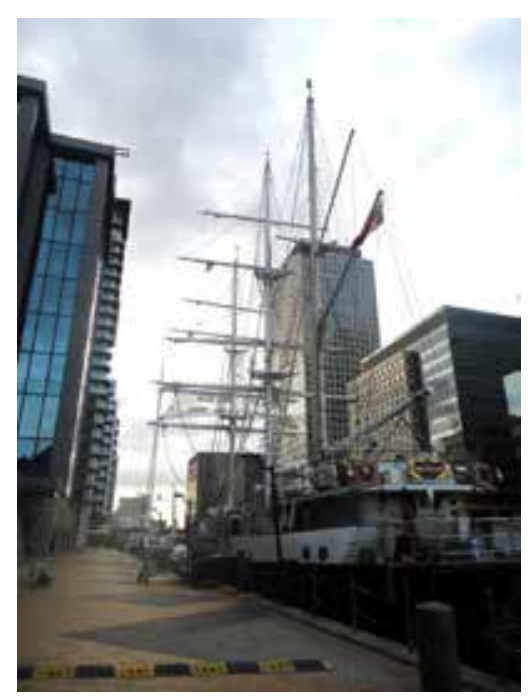

Photo 9. New embankments in London

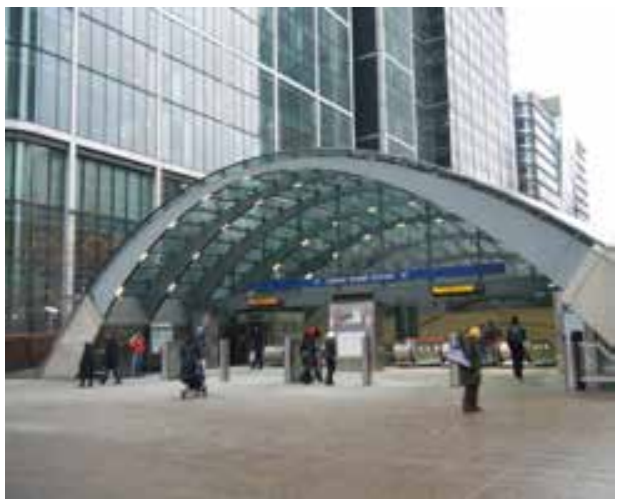

Photo 11. Jubilee line station

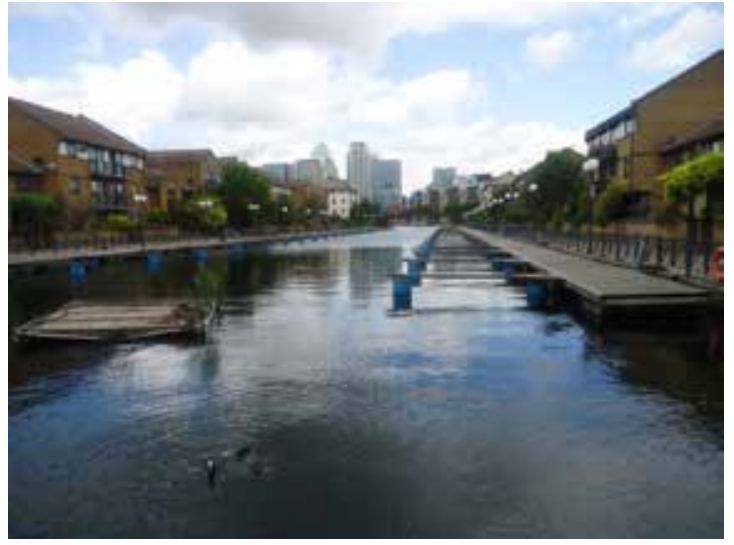

Photo 10. Recreation area on Thames

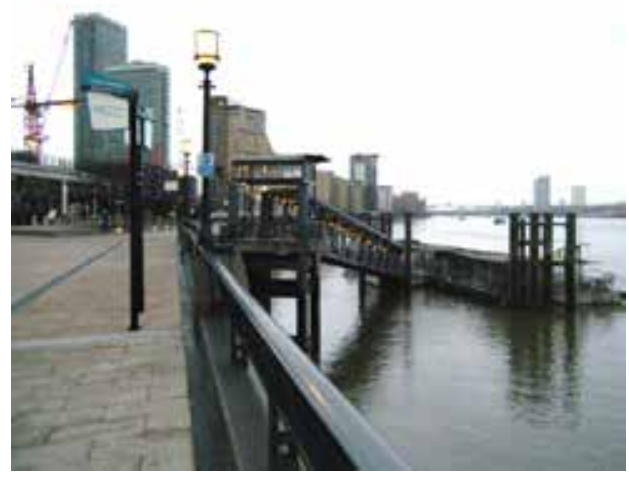

Photo 12. Water way with tram station the river provides the city with a considerable portion of open spaces, with streets running perpendicular to the river, this is a very innovative solution. All commercial activities and city configuration enable the residents to limit their car use while providing them with walking routes, subways, railways and waterbuses on the Thames.

\section{Conclusions}

In the past, potential for growth differed so results have been different. In both cities, the supply of ecosystem services refers to the capacity of a particular area to provide a specific set of ecosystem goods and services within a given period of time. Currently, there are strong differ- ences between the considered cities in their demand for ecosystem services and interaction of those with the public sphere concerning design and art. In the Isle of Dogs, there is a stronger connection between the ecosystems and the design of space to create interesting streetscape. The relationship between the public and private zone to obtain the attractiveness of the city and to combine the art and design with environmental solutions has yielded a perfect performance in London. The solutions have been brought about by the early formation of the city, they are enhanced by the relationship between the prevailing roles of the public space compared to the private one. Nevertheless, the willingness to live comfortably and the acceptance of more densely populated space gave room for the attractiveness of the city that is less cars depended. In Torun the use of 
ecosystem services focuses on private demand. The city of vast area make citizens car dependent (Artinano et al. 2004) with strong emissions into the atmosphere.

\section{References}

Artinano B., Salvador P., Alonso D. G., Querol X. \& Alastuey A., 2004, Influence of traffic on the $\mathrm{PM}_{10}$ and $\mathrm{PM}_{2.5}$ urban aerosol fractions in Madrid (Spain), Science of the Total Environment 334-335: 111-123.

Ashworth G. \& Page S. J., 2011, Urban tourism research: Recent progress and current paradoxes, Tourism Management 32: 1-15.

Boyd J. \& Banzhaf S., 2007, What are ecosystem services? The need for standardized environmental accounting units, Ecological Economics 63(2-3): 616-626.

Burkhard B., Petrosillo I. \& Costanza R., 2010, Ecosystem services - bridging ecology, economy and social sciences, Ecological Complexity 7: 257-259.

Costanza R., 2008, Ecosystem services: multiple classification systems are needed, Biological Conservation 141: 350-352.

Cowling R. M., Egoh B., Knight A. T., O’Farrell P. J., Reyers B., Rouget'll M., Roux D. J., Welz A. \& Wilhelm-Rechman A., 2008, An operational model for mainstreaming ecosystem services for implementation, Proceedings of the National Academy of Sciences of the United States of America 105(28): 9483-9488.

Czarnecki A. \& Lewandowska-Czarnecka A., 2012, Socioeconomic Versus Natural System, A Dynamic Lake Landscape: A Case Study of Jeziorak Lake in Poland, [in:] S. E. Jorgensen (ed.), Design@Nature and Ecodynamics 7(3): 261-273, WIT Press, Southampton, Boston.

Daily G. C., 1997, Introduction: What are Ecosystem Services? [in:] G. C. Daily (ed.), Nature's Services: Societal Dependence on Natural Ecosystems, Island Press, Washington, D. C.: 1-10.

Doughty M. R. \& Hammond G. P., 2004, Sustainability and the built environment at and beyond the city scale, Building and Environment 39: 1223-1233.
Egger S., 2006, Determining a sustainable city model, Environmental Modelling \& Software 21: 1235-1246.

Farber S. C., Costanza R. \& Wilson M. A., 2002, Economic and ecological concepts for valuing ecosystem services, Ecological Economics 41: 375-392.

Fisher B., Turner K. R. \& Morling P., 2009, Defining and classifying ecosystem services for decision making, Ecological Economics 68: 643-653.

Gómez-Sal A., Belmontes J.-A. \& Nicolau J.-M., 2003, Assessing landscape values: a proposal for a multidimensional conceptual model, Ecological Modelling 168: 319-341.

Gospodini A., 2006, Portraying, classifying and understanding the emerging landscapes in the post-industrial city, Cities 23(5): 311-330.

Jarrar O. M. \& Al-Zoabi A. Y., 2008, The applicability of sustainable city paradigm to the city of Jerusalem: Criteria and indicators of efficiency, Building and Environment 43: 550-557.

Kenworthy J. R. \& Laube F. B., 1996, Automobile dependence in cities: an international comparison of urban transport and land use patterns with implications for sustainability, Environmental Impact Assessment Review 16: 279-308.

Lurton B., 1998, Sustainable Cities: Oxymoron, Utopia, or Inevitability?, The Social Science Journal 35(1): 1-13.

Mega V., 2000, Viewpoint Cities inventing the civilisation of sustainability: an odyssey in the urban archipelago of the European Union, Cities 17(3): 227-236.

Millennium Ecosystem Assessment, 2005, Ecosystems and Human Well-being: Synthesis, Island Press/World Resources Institute, Washington, DC.

OECD, 2002, Governance for Sustainable Development, Five OECD Case Studies.

Rogers R., 1997, Cities for a small planet, Faber and Faber, London.

Rotmans J., van Asselta M. \& Vellinga P., 2000, An integrated planning tool for sustainable cities, Environmental Impact Assessment Review 20: 265-276.

Strange I., 1997, Planning for change, conserving the past: towards sustainable development policy in historic cities?, Cities 14(4): 227-233. 